\title{
THE NEW HANDBOOK OF POLITICAL SOCIOLOGY
}

\author{
Thomas Janoski, Cedric de Leon, Joya Misra i Isaac William Martin, \\ Cambridge University Press, Cambridge, 2020., 1142 str.
}

\section{Marko Grdešić \\ Fakultet političkih znanosti \\ Sveučilište u Zagrebu \\ E-mail: marko.grdesic@fpzg.hr}

\author{
Recenzija knjige \\ Zaprimljeno: 28. 10. 2021. \\ Prihvaćeno: 12. 11. 2021.
}

Priručnik koji su uredili Janoski, de Leon, Misra i Martin (2020a), objavljen 2020. godine, daje svježi pregled područja političke sociologije. Za čitatelje koji se bave političkom sociologijom ili se pak interesiraju za nove trendove u tom području ova knjiga predstavlja najnoviji i najiscrpniji vodič. U odnosu na starije preglede (npr. Nash i Scott 2001; Nash 2010), ovaj je priručnik opsežniji te pod svoj široki šator sakuplja velik broj relativno odvojenih znanstvenih područja. U njemu se mogu pronaći klasične teme političke sociologije kao što su država, klase, svjetski sistem i društveni pokreti ali i novije pojave kao što su društvene mreže, postkolonijalne teme, migracije, populizam, pitanja roda i seksualnosti i drugo.

Kako autori navode u uvodnom poglavlju (Janoski et al. 2020b), politička sociologija je vremenom proširila svoj fokus pa je danas riječ o veoma dinamičnoj disciplini koja se teško može svesti na nekoliko pojmova i pristupa. Kako se područje širilo, tako je izgubilo koherentnost koja je u prethodnim razdobljima karakterizirala političku sociologiju. Naime, autori sugeriraju da se razvoj političke sociologije može promatrati kroz nekoliko više ili manje jasno odvojenih valova.

Prvi je val određen istraživanjima političke moći u kontekstu hladnog rata te je povezan s klasičnom knjigom Seymoura Martina Lipseta (1969 [1963]) Political Man (domaći se prijevod odlučio za Političkog čovjeka što nam daje nešto manje seksistički naslov). U takvoj se političkoj sociologiji prije svega promatra klasna osnova političkog ponašanja. To je ujedno i temelj za razlikovanje političke sociologije od političke znanosti, premda su granice između te dvije discipline bile i ostale porozne.

Drugi je val bio pokrenut makropovijesnim studijama poput klasične knjige Barringtona Moorea (2000 [1966]) o nastanku liberalnih demokracija u zapadnim zemljama. Fokus je ostao na klasama, tj. na relativno tvrdoj društvenoj strukturi, samo što je fokus proširen na znatno duža vremenska razdoblja kao i na "velike" ishode društvenih procesa poput revolucija. Društveni sukobi i koalicije pojedinih klasa i društvenih sektora ključ su za objašnjavanje takvih ishoda na makropolitičkoj razini. Studija Thede Skocpol (1979) o revolucijama jedna je od najčitanijih knjiga koja je proizašla iz tog vala. Ove su studije bile značajne i u razvijanju komparativnih metoda političke analize.

$S$ trećim se valom počinje gubiti koherentnost discipline. Politička sociologija širi teme kojima se bavi i teorijske koncepte koji motiviraju istraživanje. Od kraja devedesetih godina prošlog stoljeća, politička sociologija se okreće kulturalnim pristupima, feminizmu, postmodernim autorima kao što su Foucault i autorima van 
tvrde marksističke jezgre kao što su Gramsci i Bourdieu. Ugrubo govoreći, taj "zaokret kulturi" umnožio je fenomene koje je potrebno proučavati jer se i politička moć počela promatrati na disperziran način. Moć nije više nešto što se tiče isključivo države, stranaka, klasa i pokreta već postoji u mnogo kompleksnijim varijantama u čitavom društvu. Pokušaj sinteze trećeg vala može se pronaći u studiji Julije Adams, Elisabeth Clemens i Ann Orloff (2005). Relativno jednostavna kvantitativna analiza tipična za istraživanja prvog vala i strukturna komparativna analiza koja je karakterizirala drugi val bivaju djelomice zamijenjene kvalitativnim i diskurzivnim metodama. Pogotovo se može pratiti utjecaj francuskih intelektualaca, poput Foucaulta i Bourdieua, na inače ipak pozitivistički orijentiranu američku sociologiju. Kao primjeri se mogu izdvojiti knjige Philipa Gorskog (2003) o nastanku države i "discipliniranju" i Julije Adams (2007) o "obiteljskoj državi" rane moderne Europe.

Urednici ovog priručnika smatraju da četvrti val počinje posljednjih godina i očekuju dodatnu proliferaciju pristupa i koncepata bez ujedinjujuće istraživačke agende. Politička sociologija danas ulazi u nova područja šireći paletu metoda i teorijskih koncepata koje koristi. Primjerice, ovaj priručnik pokriva zaista široki spektar tema: novi i stari mediji, javne financije, zatvori, klijentelizam, kozmopolitizam itd. Politička sociologija je otišla mnogo dalje u odnosu na Lipsetovu hladnoratovsku analizu političkog ponašanja. Ako se nastavi širiti kao što autori ovog priručnika pretpostavljaju, onda ni tisuću stranica, koliko otprilike broji ovaj priručnik, neće biti dovoljno da se pokriju svi relevantni doprinosi. U tom procesu granice između političke sociologije kojom se uglavnom bave sociolozi i, primjerice, komparativne politike kojom se uglavnom bave politolozi, postaju sve mutnije pa vjerojatno ni nema mnogo smisla na njima inzistirati.

Ukoliko se mogu locirati neki zajednički nazivnici u tom velikom i heterogenom području onda bi to mogli biti neki koncepti koji su se pokazali kao veoma popularni. U svojoj je osnovi politička sociologija uvijek bila zainteresirana za odnose moći i političke nejednakosti. Gramscijanska i foucaultovska perspektiva u tome su se pokazale kao korisno ishodište. Slično vrijedi i za Bourdieuov koncept "polja" koji je svoje poklonike našao u više područja političke sociologije. Tako se i država, taj klasični predmet političke analize, pretvara u nešto što je heterogeno, nekoherentno, kontradiktorno. Država "ima mnogo ruku" (Janoski et al. 2020b: 6) ili, kako bi se u domaćem kontekstu reklo, "ne zna lijeva što radi desna". Osim toga, u četvrtom se valu piše o kompleksnoj političkoj nejednakosti koja se može temeljiti na različitim osnovama poput roda, klase, etniciteta i rase, koje se pak mogu presijecati i kombinirati na različite načine.

Svi koji traže pregled korisnih referenci te uvod u neko područje unutar političke sociologije ovdje će pronaći ono što trebaju. Ovaj je priručnik u tom smislu mnogo korisniji od starijih, gore navedenih koji nisu bili dovoljno opsežni. Ako se može dati neka zamjerka ovom priručniku onda bi to bila činjenica da se on uglavnom fokusira na radove autora s američkih sveučilišta. To je razumljivo, $s$ obzirom na to da su američke društvene znanosti najutjecajnije na svijetu, ali nedostaje perspektiva drugih dijelova svijeta. To je djelomice korigirano poglavljima autora van SAD-a. Međutim, riječ je tek o pet poglavlja, a četiri od njih napisali su autori i autorice koji rade u Zapadnoj Europi, dok je tek jedna autorica iz "trećeg svijeta", u ovom slučaju iz Južnoafričke Republike. S obzirom na to da se priručnik među ostalim bavi i globalnim nejednakostima i postkolonijalnim pitanjima, šteta je da se ta načelna orijentacija nije odrazila i na odabir autora i autorica koji su uključeni u zbornik. 


\section{Literatura}

Adams, J., Clemens, E, i Orloff, A. (2005). Remaking Modernity: Politics, History and Sociology. Durham: Duke University Press.

Adams, J. (2007). The Familial State: Ruling Families and Merchant Capitalism in Early Modern Europe. Ithaca: Cornell University Press.

Gorski, Philip S. (2003). The Disciplinary Revolution: Calvinism and the Rise of the State in Early Modern Europe. Chicago: Chicago University Press.

Janoski, T., de Leon, C., Misra, J., i Martin, I. W. (2020a). The New Handbook of Political Sociology. Cambridge i New York: Cambridge University Press.

Janoski, T., de Leon, C., Misra, J., i Martin, I. W. (2020b). Introduction: New Directions in Political Sociology. U: T. Janoski, C. de Leon, J. Misra i I. W. Martin (ur.), The New Handbook of Political Sociology (str. 1-32). Cambridge i New York: Cambridge University Press.

Lipset, S. M. (1969). Politički čovek: Društvena osnova politike. Beograd: Rad.

Moore, B. (2000). Društveni koreni diktature i demokratije: Vlastelin i seljak u stvaranju modernog sveta. Beograd: Filip Višnjić.

Nash, K. (2010). Contemporary Political Sociology: Globalization, Politics and Power. Malden i Oxford: Blackwell.

Nash, K., i Scott, A. (2001). The Blackwell Companion to Political Sociology. Malden i Oxford: Blackwell.

Skocpol, T. (1979). States and Social Revolutions: A Comparative Analysis of France, Russia and China. Cambridge: Cambridge University Press. 